The final, published version of the text is available online at:

http://booksandjournals.brillonline.com/content/journals/10.1163/156920611x 564635

Word count: 10088 (plus footnotes)

Biographical statement: Tom Bunyard lives in Brighton, England, and is currently completing a PhD at Goldsmiths, London, on Debord's theory of spectacle.

Abstract: This essay reads Guy Debord's theoretical work through its primary philosophical and theoretical influences, and in doing so draws attention to his concerns with time and history. These concerns are used as a means of clarifying Debord's theory of 'spectacle' and of highlighting its virtues and failings. The essay uses Debord's remarks on subjectivity and temporality to pursue the theoretical dimensions of his interest in strategy, and thereby addresses his Hegelian Marxism via his comments on the relation between strategy, history and dialectics. His concerns with temporality are however also shown to pertain to the theory of spectacle's shortcomings as an account of capitalist society. The essay thus attempts to draw out some of the more neglected foundational material upon which the theory of spectacle rests, contending that the former may be of greater contemporary interest than the latter.

Key Words: Debord, Dialectics, Hegel, History, Marx, Situationist, Spectacle, Strategy, Time.

\title{
Debord, Time and History
}

In 1979, seven years after the Situationist International's (S.I.) dissolution, Guy Debord claimed that "the S.I. is like radioactivity: one speaks little of it, but one detects traces of it almost everywhere, and it lasts a long time." 1 Today however the group and its practices are spoken of a great deal, and perhaps to the detriment of their corruptive aspirations. Their anti-art stance has been canonised into the pantheon of art history, and both 'psychogeography' and détournement - that "fluid language of anti-ideology" - have become tropes of popular culture. In 1966 the judge presiding over the closure of Strasbourg student union felt compelled to describe Situationist ideas as "eminently noxious", and warned that their "diffusion" constituted a genuine "threat"; 3 today, by contrast, they are actively taught within the 
university environment. Outside the lecture hall their popularity has led to the French State's purchase of Debord's archives ${ }^{4}$ and to the use of Situationist texts in the promotion of French culture. ${ }^{5}$

One is thus tempted to ask whether this material was ever truly 'noxious' or 'radioactive' in the first place; a question to which I'll respond here in relation to Debord's much adopted, yet much misunderstood theory of 'spectacle'. ${ }^{6}$ I'll address this theory by way of Debord's concerns with time, history and subjectivity, which I'll contend underlie his oeuvre. I'll show that temporality - by way of its relation to subjectivity and historical agency - is not only foundational for Debord's theoretical work, but also central to the S.I.'s broader ambitions. In consequence, I'll suggest that these themes can be used not only to clarify the meaning of Debord's theory, but also to highlight its failings and virtues; and through doing so, I'll argue that if any aspect of this material can be classed as 'noxious' then it is perhaps not the theory of spectacle itself.

I'll suggest that Debord's theory can be seen to base its critique of capital's 'appearances' on those appearances, occluding the social relations from which they arise and thus perpetuating the fetishism that it sought to attack. Yet if one addresses the theory through its concerns with time and history one can perhaps access something that may be rather more interesting, and perhaps also rather more pertinent: for these issues can also be used to address Debord's often noted, yet largely unexplored concerns with strategy and chance. Furthermore, if the themes of time, history and strategy are taken together, one may be able to go some way towards reconstructing and evaluating the salient aspects of Debord's Hegelian Marxism. I'll show that the latter's emphasis on praxis, autonomy and antidogmatism drives this material's militancy, and thus perhaps also prompts its contemporary interest. Consequently, and as opposed to those who would claim that Debord's relevance lies in the homologies between his theory of spectacle and more recent notions of 'subsumption', 7 'real abstraction'8 or 'semio-capitalism', ${ }^{9}$ I'll contend that the ideas that found that theory may be of greater significance. I'll also advance the contention that these more foundational concepts actively invite the supersession of the theory of spectacle; and towards the end of the paper I'll also propose that they can in fact be seen to stand in contradiction to it.

The importance of time and history to this material can perhaps be illustrated by way of the following initial clarification of Debord's concept of

4 Gallix 2009

5 The most recent English translation of The Real Split in the International was "supported by the French Ministry for Foreign Affairs" (S.I. 2003, p.v) and the Institut Française du Royaume Uni.

6 See also my 'Capitalism and Spectacle - The Retort Collective's Afflicted Powers', written in collaboration with the Aufheben group (Aufheben 2009, pp.47-58; see also Aufheben 1997, pp.43-8).

7 For Hardt and Negri, for example, The Society of the Spectacle "is perhaps the best articulation, in its own delirious way, of the contemporary consciousness of the triumph of capital" (Hardt and Negri 2001, p.48n).

8 Jappe 1999 p.16 and passim

9 Berardi 2004 
spectacle. Contrary to what seems at times to be popular belief, The Society of the Spectacle is not a diatribe about the "mass media": Debord himself describes the latter as the spectacle's "most stultifyingly [écrasante] superficial manifestation", ${ }^{10}$ and states that the spectacle "cannot be understood as a product of the technology of the mass dissemination of images." ${ }^{11}$ The reading that will be advanced here will address Debord's claims that the spectacle is a "paralysed history": an "abandonment of any history founded in historical time", and thus "in effect a false consciousness of time". ${ }^{12}$

In short, the spectacle denotes a relationship with history, or more precisely an alienated relation to the construction of history. Debord's famous opening détournement of Marx ${ }^{13}$ corresponds to his contention that capital's reversal of subject and object had been "perfected [achevée]": ${ }^{14}$ for where Marx had claimed that individual subjects had been reduced to the status of objects, acted upon by an economy composed of their own alienated activity, Debord held that so 'perfect' and ubiquitous was this state of affairs that these same individuals had effectively become 'spectators' of their own lives. One is thus separated from autonomous control over one's own life, and thus from history; a separation that the Situationist project sought to rectify.

This interpretation will be developed during the course of this essay, and I'll begin by introducing the connection between Debord's views on history and his concerns with strategy. To that end we might now look briefly at the "strategic conception of writing" 15 employed in his Comments on the Society of the Spectacle (1988).

\section{Strategy and history}

Debord's Comments have been described as exemplifying the melancholic perspective said to characterise his later years. Hussey, for example, writes that by 1988 - the year in which the book appeared - "there was clearly a sense of defeat in Debord's thought and demeanour". ${ }^{16}$ Merrifield notes the Comments' "dark undertow", ${ }^{17}$ and Crary describes it as "deeply pessimistic"; 18 "as pessimistic", according to Plant, "as the age in which it arises". ${ }^{19}$ However, I think it can be suggested that the book's diagnosis is by no means as straight forward as might be imagined, and that it is certainly less resigned than some have claimed.

10 Debord 1995, p.19; Debord 2006 p.772

1 Debord 1995, pp.12-3; Debord 2006 p.767

2 All quotations from Debord 1995, p.114; Debord 2006 p.834

3 "The whole life of those societies in which modern conditions of production prevail presents itself as an immense accumulation of spectacles" (Debord 1995, p.12; Debord 2006, p.766).

14 Debord 1995, p.11; Debord 2006, p.766

15 Kaufmann 2006, p.211

16 Hussey 2002, p.353

17 Merrifield 2005, p.123

18 Crary in McDonough 2004, p.462

19 Plant 200, p.153. Plant is however careful to note that "the picture [the book] paints is by no means closed and hopeless" (ibid.). 
The first thing to note here is the import of history to the Comments' analysis. Debord states in this text that "people who lack all historical sense can readily be manipulated", ${ }^{20}$ and adds that "with consummate skill the spectacle organises ignorance of what is about to happen and, immediately afterwards, the forgetting of whatever has nonetheless been understood". ${ }^{21}$ Within this "eternity of noisy insignificance" 22 nothing, in his view, has been "so thoroughly coated in obedient lies" 23 as the events of May 1968; events that he and the S.I. had claimed in 1969 indicated "the reappearance of history". ${ }^{24}$ The disappearance of history is thus linked to the deprivation of self-conscious agency, and to the denigration of a critical, independent standpoint. Yet Debord also adds the following, enigmatic claim: "to the list of the triumphs of power we should, however, add one result that has proved negative: once the running of a state involves a permanent and massive shortage of historical knowledge, that society can no longer be led strategically." 25

I'll return to this statement towards the end of this essay, after having first addressed the theory of spectacle and the ideas that inform it. I'll show that those ideas might clarify Debord's linkage of the strategic and the historical, and on that basis I'll offer a re-interpretation of the Comments in which I'll suggest that it is perhaps not quite as bleak a text as it might seem. First however I'll aim to introduce the possible import of this discussion; and this might be attempted by noting the Comments' complex unification of form and content.

Such unification was Debord's principal response to the problem of articulating a critique of spectacle within spectacular discourse. The Society of the Spectacle, for example, makes extensive use of détournement, and thus in a sense actualises its critique through its very enunciation. Many further examples can be found throughout his oeuvre, ${ }^{26}$ but the Comments is rendered particularly interesting in this respect by virtue of its account of the spectacle's 'integration' into society. ${ }^{27}$ This latter has often been said to echo Baudrillard's account of 'hyperreality', ${ }^{28}$ yet I would argue that the ideas that drive it remain as essentially Hegelian as those advanced in The Society of the Spectacle: for where that earlier text described the spectacle's immanent negation, the Comments describes the emergence of the spectacle within

\footnotetext{
Debord 2002, p.25, translation altered; Debord 2006, p.1607

Debord 2002, p.14; Debord 2006, p.1601

Debord 2002, p.15; Debord 2006, p.1062

Debord 2002, p.14; Debord 2006 p.1061

S.I. 2006, p.292; S.I. 1997, p.575

Debord 2002, p.20; Debord 2006, p.1605

6 Debord's cinematic works are similarly composed of détourné films; Debord's autobiography, Panegyric (1989), is intended to show through its "subjective extravagance", the "non-value of current society" (Debord 2008, p.228).

27 "'For the final sense of the integrated spectacle is this - that it has integrated itself into reality to the same extent as it was describing it, and that it was reconstructing it as it was describing it. As a result, reality no longer confronts the integrated spectacle as something alien." Debord 2002, p.9; Debord 2006 p.1598

28 See for example Plant 2000 and Best and Kellner 2000.
} 
that negation. ${ }^{29}$ Debord's task, therefore, was not only to give voice to the negation of the spectacle, as he had done through détournement in the past: in addition, he was to do so in a manner that highlighted and negated the spectacle at work within that opposition.

Attendant to this was Debord's concern that his work could be studied and used ${ }^{30}$ by those "who devote themselves to maintaining the system of spectacular domination"; ${ }^{31}$ an issue that led him to believe that he must "take care not to give too much information to just anybody". ${ }^{32}$ In consequence, when explaining this latter exigency at the outset of the Comments, he presented the book as a kind of puzzle: ${ }^{33}$ "readers," he warned, "will encounter certain lures, like the very hallmark of the era"; "some elements will be intentionally omitted, and the plan will have to remain rather unclear". ${ }^{34} \mathrm{He}$ maintained however that "as long as certain pages are interpolated here and there the overall meaning may appear." 35

This 'puzzle' is often noted in the literature on Debord, but it remains unsolved. Plant for example observes that "there is a great deal more to the Comments than sits on the page", ${ }^{36}$ but falls short of saying quite what is missing; Brown is also left asking what "the missing ingredient" 37 might be. Kaufmann even goes so far as to claim that "in order to describe a society in the grip of a multiplicity of secret services" Debord became "a kind of ironic Hercule Poirot", ${ }^{38}$ but he gives no indication as to quite what the great detective has hidden. I would however suggest that one can begin to resolve this problem by noting that Debord's original wording indicates that the book's 'lures' might lie in its plan or structure, and that the 'hallmark of the era' might be an 'encounter' with them: ${ }^{39} \mathrm{a}$ 'hallmark' that would then reflect the reader's own susceptibility to such deceit. This can be qualified by the following statement, taken from a letter of 1989 to a reader of the Comments:

One can call 'lure' anything that misleads rapid reading or computers. In any case, there isn't a single inexact or deceptive piece of information [in my book]. I suggest another hypothesis to you: what if, in this book - for a reader capable of

29 "For the highest ambition of the integrated spectacle is ... that secret agents become revolutionaries, and revolutionaries become secret agents" (Debord 2002 p.11, translation altered; Debord 2006 p.1599). See also Debord's comments on the demise of the S.I. in S.I. 2003.

30 This is of course easily dismissed, but see Eyal Weizman's work on the Israeli Defence Force's use of Debord, Delueze and other such writers as means of re-conceiving urban combat (Weizman 2007).

31 Debord 2002, p.1, translation altered; Debord 2006, p.1593

32 Debord 2002, p.1; Debord 2006, p.1593

33 Cf. Debord's comments on the explanatory diagrams to his 'Game of War': "before they went to the printers the figures looked like a truly daunting puzzle awaiting solution, just like the times in which we live." (Becker-Ho and Debord 2007, p.9)

34 Debord 2002, p.2, translation altered; Debord 2006, p.1594

35 Debord 2002, p.2; Debord 2006, p.1594

36 Plant 2000, p.152-3

37 Brown 1991

38 Kaufmann 2006, p.264

39 "On pourra y rencontrer, comme la signature même de l'époque, quelques leurres" (Debord 2006, p.1594). Imrie's translation of the second sentence ('readers will encounter certain decoys, like the very hallmark of the era'; Debord 2002, p.2) renders Debord's indefinite 'one will be able to' as an inevitable 'will', and loses the sense in which those 'decoys' may lie in the book's plan or structure. 
understanding dialectical, strategic thought (Machiavelli or Clausewitz) - there are in fact no lures? What if the only lure is the very evocation of the possibility of there being lures? ${ }^{40}$

A very similar point is made in Debord's Cette Mauvaise Reputation (1993) ${ }^{41}$ and again in a letter to a Spanish translator of the Comments. ${ }^{42}$ Yet what is perhaps most important here is the relation between the 'dialectical, strategic thought' that Debord requires of his readers and the lack of strategic capability that he attributed to the spectacle itself (as noted above), for this has two implications: firstly, that a failure to decipher the Comments exemplifies the symptom's of the spectacle's eradication of history; and secondly, that the skills required to thread one's way through the book would seem to pertain to those needed to traverse the integrated spectacle itself.

In a suitably dialectical manoeuvre the Comments thus uses the spectacle's own nature against it: ${ }^{43}$ the book's critique presents itself as containing 'lures' and hidden meanings, thus evoking the confused and illusory nature of the spectacle; it thereby expresses the spectacle's integration into its own opposition; through doing so, it guards its own content with the same gesture that mirrors the true nature of its object.

There are of course any number of objections that one might want to make here, not least because this runs entirely counter to any notion of popular appeal or intelligibility (Debord was never one to make concessions to his audience). ${ }^{44}$ Yet however problematic it may be, it is perhaps of broader interest than its status as a hermeneutic peculiarity: for what comes to the fore here is the sense in which Debord's association of history, strategy and dialectics offered, in his view, some sort of critical purchase on contemporary capitalism.

It's worth noting here that an increasing number of commentators have taken to making similar claims. Giorgio Agamben once wrote that Debord's books "should be used ... as manuals, as instruments of resistance or exodus", ${ }^{45}$ and with the English publication of Debord's Game of War in 2007 others have made similar claims (the Class War Games group, for example, contends that the Game of War allows "revolutionary activists to learn how to fight and win against the oppressors of spectacular society"). ${ }^{46}$ Yet in the absence of an engagement with the material that founds Debord's theory

Debord 2008, p.78

41 "Perhaps [the suggestion of lures] is a lure? Perhaps the only one?" (Debord 1993, p.33).

42 "I do not believe," Debord writes, "that one must translate 'lures', originally a term used by hunters and that evokes a lost trail, by the brutal trampa [trap] (there is no false information, which might make the reader 'fall into error', in my book)" (Debord 2008, p.93).

43 Sun Tzu is particularly apposite in this respect because of the similarity between the Taoist and Hegelian focus on interrelated opposites. See for example Sun Tzu's recommendation that one should "use the enemy to defeat the enemy" (Sun Tzu 1988, p.64). Sun Tzu in fact provides the epigraph to the Comments, and was said by Debord to be similar to Machiavelli and Clausewitz by virtue of the purportedly dialectical aspects of his work (Debord 2008, p.204).

44 See Kaufmann 2006, pp.232-8 and passim for comments on this tendency.

45 Agamben 1990 Marginal Notes

46 Class War Games, 2010 
such statements can remain no more than mere assertions. I will attempt to rectify this to some extent, but not by presenting Debord's books as esoteric field manuals: rather, I'll show that the philosophical influences that inform Debord's work can provide a means of relating his interest in strategy to his theoretical concerns and Hegelian Marxism; and through doing so, I'll aim to clarify the correlation of historical and strategic thought signalled above. I thus hope to shed some light on the mode of thought spoken of in the following passage, taken from a letter of 1974:

The principle work that, it appears to me, one must engage in - as the complementary contrary to The Society of the Spectacle, which described frozen alienation (and the negation that is implicit in it) - is the theory of historical action. One must advance strategic theory in its moment, which has come. At this stage and to speak schematically, the basic theoreticians to retrieve and develop are no longer Hegel, Marx and Lautréamont, but Thucydides, Machiavelli and Clausewitz. ${ }^{47}$

\section{Time and subjectivity}

I'll begin by looking at Debord's concerns with temporality, and we can start The Society of the Spectacle's claim (made by way of a quotation from Hegel) that "man - that 'negative being who is to the extent that he abolishes being' - is one [identique] with time". ${ }^{48}$ I would argue that the spectacle's purported 'falsity' stems from the denial of that unity with time, and I draw attention to that here as it entails dismissing the assumption that the theory of spectacle is based around the loss of an Arcadian or 'authentic' past (e.g. Kaufmann's erroneous claim that Debord "postulates a golden age, a humanity originally transparent to itself"), ${ }^{49}$ or indeed on the future realisation or re-institution of an a priori human nature..$^{50}$

The fifth chapter of The Society of the Spectacle "treats," as Debord later explained, "historical time (and the time of historical consciousness) as the milieu and goal of the proletarian revolution". ${ }^{51}$ Rather than presenting Kaufmann's 'humanity originally transparent to itself', this section of the book traces the link between forms of temporality and modes of production by describing the alienation engendered by the latter in terms of the former. During the development and evolution of these modes of social organisation the power to shape history is said to grow as it becomes increasingly separated from its producers, culminating in the 'perfected' separation of the spectacle. ${ }^{52}$ The latter is presented as a dialectical juncture at which the two

47 Debord 1974

48 Debord 1995, p.92; Debord 2006 p.820

49 Kaufmann 2006, p.222

50 Jappe: "There was no such thing, in [the S.I.'s] view, as some original human nature, complete with its desires and its imaginary register, that a bad society had later perverted" (Jappe 1999, p.131).

51 Debord 1969b

52 Crary is thus quite wrong when he writes that "a striking feature of Debord's book was the absence of any kind of historical genealogy of the spectacle" (Crary in McDonough 2004, p.456). 
extremes can re-unite.

The book thus contends that modern society (or rather the society of 1967) offers a new and previously unrealisable capacity for free selfdetermination: a capacity that stems from the conclusion of a tendency towards a potential self-consciousness of historical action. For the S.I., labour could be superseded through technological automation, ${ }^{53}$ and it was in this sense that the goal of the Situationist revolution was not the possession of the means of material production per se, but rather of the means of producing one's own life: the means of attaining the "free consumption of [one's] own time". ${ }^{54}$ This was also informed by the S.I.'s desire to 'realise' art; an ambition that deliberately echoed Marx's Young Hegelian concerns with the 'realisation' of philosophy. ${ }^{55}$ Where Sartre and the existentialists had "only interpreted situations", the S.I. would now "transform them", ${ }^{56}$ and in doing so they would unite art and life through the creative, self-determined construction of subjective experience. "The point", Debord claimed in The Society of the Spectacle, was "to take effective possession of the community of dialogue, and the playful relationship to time, which the works of the poets and artists have heretofore merely represented". ${ }^{57}$

These aspirations, together with the notion that society might be located at a grand historical juncture, relate to the S.I.'s response to then prevalent question of the absence of a $19^{\text {th }}$ Century proletariat. The latter, as Vaneigem put it, had seemingly "disappeared forever beneath an avalanche of sound systems, T.V.'s, small cars and planned communities". ${ }^{58}$ Yet for Debord and the S.I., a "new poverty" and a "new proletariat" ${ }^{59}$ had emerged: a 'higher' form of poverty that revealed the true, implicit nature of its predecessor. The deprivation of the means of subsistence necessarily entails the deprivation of the power to freely shape one's existence; thus, whilst the 'wealth' of commodity society had remedied the former problematic, the ennui that this 'wealth' had engendered rendered the latter explicit. Consequently, the S.I. felt able to claim that "in the context of the reality presently beginning to take shape, we may consider as proletarians all people who have no possibility of altering the social space-time that society allots to them." 60

I'll return to the implications of that reformulation below, when discussing the failings of the spectacle as an account of the operation of capital. Here I simply want to indicate the almost existential notion of poverty and authenticity that it involves: for despite his stated antipathy to the chief proponents of existentialism, ${ }^{61}$ the manner in which Debord and the S.I. cast the human subject as the product of its own experiences and actions owes

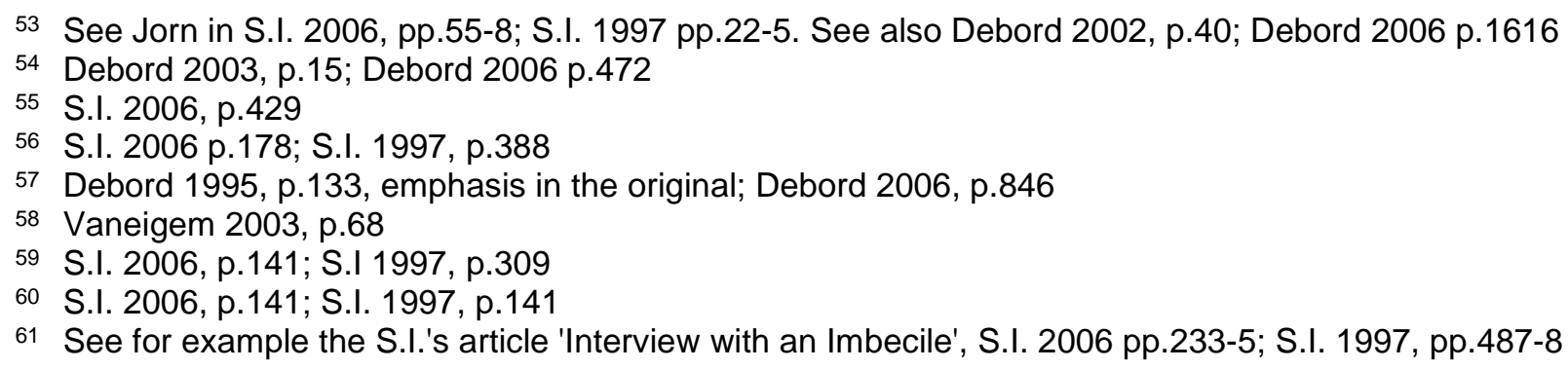


much to existentialism's legacy and ambience, as indeed does his focus on temporality (although I would also add that his interest in time is also inflected by French Hegelianism's interest in Hegel's association of consciousness, time and dialectics). ${ }^{62}$ This is by no means to deny that these notions of selfdetermination and self-constitution can be discerned in the more obvious influences of Hegel, ${ }^{63}$ Marx, ${ }^{64}$ Lukács ${ }^{65}$ and Lefebvre; ${ }^{66}$ rather, it is to suggest that the French milieu of the 1950's and 60's furthered an emphasis on those aspects of Hegelian Marxism. The principal issue however is that Debord effectively founds the existential view that "one is what one does" 67 upon a Hegelian Marxist model of dialectical interaction between subject and object. $^{68}$ This will be developed below when I turn to Debord's views on Marx's 'inversion' of Hegel, but here we can note that it underlies his claim that the subject is both 'negative' and 'one with time': for as that subject abolishes what exists by creating itself and its world anew through its own actions, and insofar as it comes to know itself through that process, both the subject and its world - qua their continual differentiation - are cast as inherently historical. ${ }^{69}$

The corollary of this view is that a denial of self-determination - brought about through the restriction of such options and the imposition of set, predetermined experiences - would constitute not only a denial of the self, but also a separation from one's own time: for if one is and knows oneself through what one does, then abdicating autonomy gives rise to a separation from one's own objective activity, and thus to an absence of selfconsciousness. ${ }^{70}$

Whilst this owes a great deal to Marx's early discussions of alienated labour, it also exhibits (as Jappe has stressed) ${ }^{71}$ the influence of Lukács' History and Class Consciousness (1923). According to Lukács, the alienation of the subject from his or her own activity entails an increasingly

62 This association is brought to the fore in the work of Wahl, Koyré, Kojève and Hyppolite. I would also suggest that Kojeve's infamous interpretation of Hegel's 'end of history' provided one of the principal templates for Debord's theory.

63 "An individual cannot know what he is until he has made himself a reality through action" (Hegel 1977, p.240).

64 "Objective man ... [is] the outcome of man's own labour" (Marx 1988, p.149). "Labour is ... a process between man and nature ... Through this movement he acts upon external nature and changes it, and in this way he simultaneously changes his own nature" (Marx 1990, p.283).

65 "To posit oneself, to produce and reproduce oneself - that is reality" (Lukács 1971, p.15).

66 "An individual can imagine himself to be a nebula (a cloud) of virtualities (possibilities). ... The processes of his practical life consists of a sort of constellation of actions and powers (capacities)" (Lefebvre 2008, p.112).

67 Heidegger 2008, p.283

68 e.g. "in the working-up of the objective world. ... nature appears [to the acting subject] as his work and his reality ... for ... he duplicates himself not only, as in consciousness, intellectually, but also actively, in reality, and therefore contemplates himself in a world that he has created" (Marx 1988, p.77).

69 Lefebvre: "The human being is historical and its historicity is inherent to it: it produces and is produced, it creates its world and creates itself." Lefebvre 2008b, p.20

70 Just as Hegel wrote that "the slave knows not his essence ... and not to know himself is not to think himself," (Hegel 2005, p.xlii), Debord held that "the more [the spectator] contemplates ... his own unthinking activity ... the less he understands his own existence and his own desires" (Debord 1995, p.23; Debord 2006, p.774)

71 Jappe 1999, pp.19-31 and passim. 
"contemplative"72 attitude towards the latter; an attitude that had, as a result of society's domination by the commodity form, begun to spread beyond the factory walls. Debord adopts and expands this position, claiming that all social activity now takes place in accordance with the demands of the economy. ${ }^{73}$ His contention is thus that the dialectical relation of mutual constitution between self and world has been subverted, resulting in a passive subject acted upon by an alien world; albeit a world composed, qua commodification, of that subject's own alienated power and activity. ${ }^{74}$

To sum up: the claim that the human subject has been separated his or her own time unites the Marxist idea of separation from one's own activity with a desire to supersede the separation of art and life, insofar as both were to be overcome through the revolutionary institution of free self-determination (this was originally to be achieved through the construction of situations, but as the S.I. developed it became increasingly associated with libertarian council communism). It is in this respect that the concept of spectacle is intended to articulate not only the inadequacy of contemporary capitalism, but also the possibilities of a post-revolutionary future.

\section{Image and representation}

Before expanding on these themes I'll offer some brief notes as to the extent to which their disavowal has furthered a reductively literal reading of Debord's visual terminology. This is largely due to the academic trends that have characterised Debord and the S.I.'s appropriation, and which have resulted in the theory's separation from its Hegelian roots. ${ }^{75}$ Jappe's Guy Debord (1993 in Italian; 1999 in English) remains the sole text to approach Debord's Hegelian Marxism in detail, and given this solitary status it's interesting to note that Debord himself described it as "the best-informed book about me". ${ }^{76}$ Yet although Jappe's book certainly brought this dimension of Debord's theory to the fore, it does so largely uncritically (Debord also

72 “... activity becomes less and less active and more and more contemplative” (Lukács 1971, p.89, emphasis in the original).

73 "The spectacle subjects [soumet] living men to its will to the extent that the economy has totally subjugated [soumis] them" (Debord 1995, p.16, translation altered; Debord 2006, p.769), as the whole of modern life now takes place in "uneasy and worshipful subjection to production's needs and results" (Debord 1995, p.21; Debord 2006, p.773)

74 "Workers do not produce themselves: they produce a force independent of themselves" (Debord 1995, p.23; Debord 2006, p.774)

75 Although the group's connection to the radical left was never entirely forgotten or abandoned, they came to be adopted by a more cultural and artistic milieu from the late 70's onwards. The exhibition of Situationist work in the late 1980's laid the basis for the art-historical and visual cultural readings that would later proliferate (e.g. Beller 2006, Crary 2001, Jay 1994, Mitchell 1994). This encouraged the assumption that Debord's use of the terms 'image' and 'representation' should be read in a simplistically visual register, i.e. as denoting pictures, adverts and the mass media, which fostered both the theory's appropriation by media studies and its supposed connection to 'postmodern' notions of 'simulacra' and 'hyperreality' (e.g. Best and Kellner 2000, Plant 2000). The result of this line of development is thus a denigration of the Hegelian ideas that make Debord's theory fully comprehensible.

76 Debord 2008, p.453 
noted the book's "comprehensive sympathy"). ${ }^{77}$ Jappe addresses Debord's Hegelianism largely by way of the influence of Lukács; and although he recognises Debord's interests in time and strategy, he offers little discussion of the manner in which they cohere, or indeed how they might relate to his Hegelianism or to the rest of his work. Furthermore, although the appearance of Jappe's book has entailed that most writers now at least mention Debord's Hegelianism ${ }^{78}$ few seem to engage with it. Debord's own observation that that "one cannot fully comprehend" The Society of the Spectacle "without Marx, and especially Hegel"79 thus continues to ring true.

In their absence The Society of the Spectacle can indeed be opaque: Kaufmann for example, who admits that "the enthusiasm shown ... for Debord the theoretician often leaves me ... sceptical", ${ }^{80}$ informs us on a page that contains no less than nine rhetorical questions ("Do we know exactly what Debord means by spectacle? Can we know?", etc.), ${ }^{81}$ that the book is "an enigma". ${ }^{82}$ Yet by far the most prevalent error - as widespread as its following formulation is crude - is that encapsulated by a frustrated JeanPierre Voyer: he "used to go to bed late, hoping to find an idea in Guy Debord's book"; he discovered that "there are none", and he concludes from this that "when Debord pompously writes 'everything that was directly lived has withdrawn into a representation', the prick is simply saying that we see posters of naked women pushing brands of cigarettes." ${ }^{83}$ Traces of this reading can be discerned throughout much of the literature on Debord. Beller for example is close to the mark when he tells us that the theory "is merely a reformulation in visual terms of Lukács analysis of commodity reification", 84 but he conflates 'visual terms' with visual phenomena; ${ }^{85}$ and just as Beller only half-grasps the spectacle's connection to the commodity, so too does Hussey fall short of its connection to alienation: he correctly notes that Debord is doing something "rather more nuanced" than "simply attack[ing] the obvious visual manifestations of modern society", but he believes this to be describing those visual forms as uniting "the fragmented aspects of modern life". ${ }^{86}$

Such readings go astray because of their inability to decipher Debord's visual terminology. This can perhaps be clarified by way of its largely

\footnotetext{
77 Debord 2008, p.441

78 For example, Hussey acknowledges that the theory's "first influence was Hegel" (Hussey 2002, p.216), and Bracken writes that "Hegel is ... central to Debord's thought" (Bracken 1997, p.83).

79 Debord 2004, p.454

80 Kaufmann 2006, p.xi

81 Kaufmann 2006, p.73

82 Kaufmann 2006, p.73

83 Voyer 1998

84 Beller 2006, p.241

85 This pertains to Beller's peculiar notion of an 'attention economy', in which things accrue value via the attention paid to them. His account makes extensive use of The Society of the Spectacle in making this claim, as he contends that "the visual" for Debord is "the paramount field of capital exploitation" (Beller 2006, p.278).

86 Hussey 2002, p.217
} 
overlooked ${ }^{87}$ basis in Hegel's notion of Vorstellung (often translated as 'picture thought' in English, and significantly as 'representation' in French). The Vorstellung is a mere 'image' - in the sense of a conceptual representation that remains separate from its object - of the "life pulse" 88 of the Begriff ('Concept'), and is thus a mode of thought that remains estranged from its own true nature. ${ }^{89}$ Debord's claim is that the unity of subject and object afforded by self-determined action has been denied by the spectacle, and that in separating the subject from his or her own activity spectacular society becomes a representation of that unity.

This might be explained by way of a few words on the derivation of this connection between alienation and representation, which stems in part from Feuerbach's presentation of religion as a Vorstellung of human 'speciesbeing': "Man," he claimed, first of all sees his nature as if out of himself, before he finds it in himself," 90 as "God" is no more than "the mirror of man" 91 (a view echoed by the early Marx). ${ }^{92}$ Debord's spectacle and its representations also involve a notion of reflection ${ }^{93}$ and speculum; ${ }^{94}$ yet being the "material reconstruction of the religious illusion," 95 these images are not merely ideological, but rather involve social practice itself. ${ }^{96}$ Their 'inverted' nature stems from Marx's depiction of a humanity in thrall to its own alienated activity, ${ }^{97}$ which pertains to the notion of falsity outlined above. It's important to note however that Debord's 'images' are not Vorstellungen of an original essence, but rather of the capacity for self-determination via subject-object unity (a point that I'll return to below).

As noted above, the concept of spectacle was not only intended to define its age but also the latter's capacity for historical change; an intention

87 Bracken mentions the phrase 'picture-thinking' once when signalling the influence of Hegel's aesthetics (Bracken 1997, pp.82-3), but he does not analyse the concept or establish its connection to alienation, praxis or spectacle.

88 Hegel 1998, p.37

89 For example: religion for Hegel is the "inmost region of Spirit"; yet even its highest form, the "revealed religion" (Hegel 1977, p.453) of Christianity, remains a mere Vorstellung of the Absolute identity of identity and difference accessed by grasping the Begriff through Hegelian philosophy. Crucially, such a representation is not false qua its absolute distinction from the Concept: rather, the Concept is its own true alienated nature, which it has yet to be united with (hence Hegel's claim that the Christian religion's "actual self-consciousness is not the object of its consciousness", despite which he contends that "the content of this picture-thinking is absolute Spirit" (Hegel 1977, p.479)).

90 Feuerbach 1989, p.13

91 Feuerbach 1989, p.63

92 See for example his comments in his 'Introduction to a Critique of Hegel's Philosophy of Right': "Man has found in the imaginary reality of heaven where he looked for a superman only the reflection of his own self" (Marx 2005, p.71).

93 The spectacle is "the faithful [fidèle] reflection of the production of things, and a distorting [infidèle] objectification of the producers." (Debord 1995, p.16; Debord 2006, p.769)

94 "In French, 'spectacle' has the merit of being linked to the Latin speculum and thus to mirror, to the inverted image, to the concept of speculation, etc." (Debord 1980)

95 Debord 1995, pp.17-8; Debord 2006, pp.770-1

96 "... the spectacle cannot be set in abstract opposition to concrete social activity" (Debord 1995, p.14; Debord 2006, p.768).

97 "Just as man is governed, in religion, by the products of his own brain, so, in capitalist production, is he governed by the products of his own hand" (Marx 1990, p.772). Cf. Debord's claim that "Our era accumulates powers and imagines itself as rational. But no one recognizes these powers as their own." (Debord 2003, p.30; Debord 2006, p.543) 
that stems from Debord's goal of capturing society as a historical totality, which echoes Lukács' own attempt to understand society under the general rubric of the commodity. ${ }^{98}$ The difference is that for Debord the commodity's dominance had necessitated a new totalising concept, able to express the changes wrought by this ubiquity. 'Spectacle' thus combines a 'perfected' alienation, the need to overcome art's representation of life, but also - and here we come to the media and visual aspects of the theory - a sense in which the separation of subject and object had reached such an extreme that it was now made manifest in a society saturated with visual imagery extolling capital's virtues (hence, the spectacle is "a negation of life that has become visible"). ${ }^{99}$ Lukács' 'contemplative attitude' had thus truly come to define modern society. These contentions also informed Debord's interest in the cinema, which was said to be "the best representation of an epoch"100 (see also Lefebvre: "someone sitting in front of a cinema screen offers an example and a common model of [modern] passivity"). ${ }^{101}$

The media-centric reading of spectacle is thus not wrong per se: rather, it focusses on the spectacle's most 'stultifyingly superficial' aspects, and fails to see their connection to the broader themes of history, time and selfdetermination. As Debord put it in his correspondence: "behind the phenomenal appearances of the spectacle (for example, television, advertising, the discourse of the State, etc.), that is to say, particular mendacious forms, one can find the general reality of the spectacle itself (as a moment in the mode of production)."102

This however leads us to the problems inherent within his theorisation of that mode of production. Having outlined these difficulties I will then return to the issue of time, and thereby to the themes of strategy and history signalled above.

\section{Spectacle and capital}

I'll suggest here that the theory of spectacle's inadequacy as an account of the operation of capital stems from Debord's choice of totalising concept: for despite encompassing the issues indicated above, the notion of 'spectacle' stresses the subjective alienation of consciousness over the objective alienation of activity (i.e. the sale of labour within the capital relation). Theorising society as a totality under the rubric of contemplation subsumes the specificity and diversity of activity under the ubiquity of alienated consciousness, and thus casts production, circulation, work, leisure etc. as effectively homogeneous. Or, as Dauvé puts it: Debord and the S.I. "criticized

\footnotetext{
98 According to Lukács, "The commodity can only be understood in its undistorted essence when it becomes the universal category of society as a whole". (Lukács 1971, p.86) Debord quotes this very same passage as the epigraph to the second chapter of The Society of the Spectacle.

99 Debord 1995, p.14, translation altered; Debord 2006, p.768

100 S.I. 1997, p 8

101 Lefebvre 2008 a p.32

102 Debord 1973
} 
the commodity, not capital - or rather ... criticized capital as commodity, and not as a system of valuation which includes production as well as exchange." 103 In short, Debord's theory attempts to understand social production on the basis of consumption, remaining within the "sphere of circulation" without entering "the hidden abode of production"; 104 and as a result, its critique of appearances is itself founded in part on appearance.

That claim can be introduced by enquiring as to whether Debord fell prey to the idealism that Lukács later identified within his History and Class Consciousness. "Man," he claimed in 1923, "must become conscious of himself as a social being, as simultaneously the subject and object of the socio-historical process." ${ }^{105}$ This entailed that "society becomes the reality for man," 106 and that "nature" became a "social category." ${ }^{107}$ However, in his long and self-effacing preface to the book's 1967 edition, Lukács wrote that its presentation of nature as a social construct had effaced the independence of the real, objective world. History and Class Consciousness, he claimed, had made the mistake of equating the 'otherness' of the world and the objective actions performed within it to the alienation engendered by capital: to use Marx's terms from the 1844 Manuscripts (the reading of which led Lukács to recognise his own overly subjective errors), ${ }^{108}$ Entäusserung (the subject externalising itself through its own activity) was thus blurred with Entfremdung (estrangement from that activity), as all instances of the former were viewed in terms of the latter. Consequently, according to the Lukács of 1967, "labour, the mediator of the metabolic interaction between society and nature, is missing [from the book]". ${ }^{109}$ His critique of contemplation had fallen back into the "idealistic contemplation"110 of capital's subjective effects: "the proletariat seen as the identical subject-object of history" was thus "an attempt to outHegel Hegel", and "an edifice boldly erected above every possible reality". ${ }^{111}$

Debord avoids this problem by way of his concern with time, but fails to do so in an entirely satisfactory manner. "Time", he writes, is "a necessary alienation", ${ }^{112}$ being "the medium in which the subject realises himself while losing himself, becomes other in order to become truly himself [pour devenir la vérité de lui-même]". ${ }^{113}$ The object with which this subject was to unite was thus its own action, not nature per se, and a degree of 'necessary' otherness and externalisation was thus retained within that unity. However, Debord's

\footnotetext{
103 Dauvé 1979

104 Marx 1990, p.279

105 Lukács 1971, p.19

106 Lukács 1971, p.19

107 Lukács 1971, p.234. In other words, "whatever is held to be natural at any given stage of social development" is "socially conditioned"(ibid.).

108 "In the process of reading the Marx manuscript [the Economic and Philosophical Manuscripts of 1844] all the idealist prejudices of History and Class Consciousness were swept to one side" (Lukács 1971, p.xxxvi).

109 Lukács 1971, p.xvii)

110 Lukács 1971, p.xviii

111 Lukács 1971, p.xxiii)

112 Debord 1995, p.115; Debord 2006, p.835

113 Debord 1995, pp.115-6; Debord 2006, p.835
} 
theory does not entirely escape the charge of subjectivism, for although it presents capital as the result of alienated social activity it offers little purchase on the social relations from which capital arises. The theory of spectacle presents all social activity as being effectively homogeneous, because the extension of reification and rationalisation beyond the factory walls gives rise to a society in which "time" (to borrow Lukács' phrasing) "sheds its qualitative, variable, flowing nature", and is thereby "transformed into abstract, exactly measurable"114 space. Yet just as this time had become abstract and generalised across social experience, so too had Debord's proletariat: as we've seen, the latter had "not been eliminated" by the 'wealth' of commodity capitalism, but rather remained "irreducibly present ... in the shape of the vast mass of workers who have lost all power over the use of their own lives"; 115 a 'vast mass' that crossed the class boundaries of traditional Marxist analysis, being formed, as we saw above, of 'all people who have no possibility of altering the social space-time that society allots to them', "regardless of variations in their degrees of affluence". 116

Debord's effectively existential notion of poverty was thus linked to the nature of 'spectacular time': a time that "manifests nothing in its effective reality aside from its exchangeability", ${ }^{117}$ as all social experience and activity had been broken down into abstractly equivalent, functional chunks. Different forms of social activity were thus equated to one another (furthered by the trope of a disconnected spectator, for whom all life is equally separate), thus denigrating the importance of wage labour vis a vis the analysis of capital and informing the S.I.'s shift in focus away from production towards the 'everyday' (remembering here their contention that labour was to be abolished by automation). In short, capital's basis in the objective activity of production was neglected as a result of the emphasis that Debord and the S.I. placed on its subjective effects.

Yet despite the sense in which the revolutionary project was presented as having effectively outgrown any preordained focus on surplus value ${ }^{118}$ the theory of spectacle does nonetheless rely on Marx's notions of fetish and appearance; concepts that were intimately linked to the latter's account of the wage relation. ${ }^{119}$ Debord was thus obliged to expand that relation in a manner that would allow him to talk of the alienation of life as a whole rather than

\footnotetext{
114 Lukács 1971, p.90

115 Debord 1995, p.84; Debord 2006, p.816

116 S.I. 2006 p.141; S.I. p.309

117 Debord 1995, p.110, emphasis in the original; Debord 2006, p.831

118 Debord in fact write that Marx had been drawn onto the terrain of the dominant forms of thought" in that he took up "the fundamental science of bourgeois society, political economy" (Debord 1995, p.55, translation altered; Debord 2006, p.797); he seems to have viewed this as being tantamount to 'economism', and thus to the perpetuation of the abdication of historical agency to "the products of men's hands" (Marx 1990, p.165).

119 "The wage form ... extinguishes every division of the working day into necessary and surplus labour ... All labour appears as paid labour. ... All the notions of justice held by both the worker and the capitalist, all the mystifications of the capitalist mode of production, all capitalism's illusions about freedom, have as their basis [this] form of appearance, which makes the actual relation invisible, and indeed presents to the eye the precise opposite of that relation" (Marx 1990, p.680).
} 
labour per se. This however renders that relation so abstract that it effectively becomes a binary opposition rather than a dialectical interaction: within the spectacle "the entirety of labour sold", i.e. the total activity of society, becomes "the total commodity", ${ }^{120}$ i.e. spectacular life, which is then returned in fragments to its fragmented producers. The social, interpersonal antagonism of the wage relation thus becomes the opposition of 'humanity' as a whole to 'capital', or rather of 'life' to its denial. Thus, although the theory of spectacle relies on traditional Marxist concepts it removes their bases; hence the contention that it's account of appearances is itself founded on appearance, insofar as its use of the concept of fetish could in fact be said to exemplify the fetish, as it occludes the social relations from which capital arises.

This of course stems from the S.I.'s desire to open up a "Northwest Passage" through and beyond $19^{\text {th }}$ Century analyses and the models of struggle and organisation associated with them. ${ }^{121}$ Debord and the S.I.'s rejection of any sense in which labour might be liberated rather than abolished also recalls aspects of Postone's work, ${ }^{122}$ and for some, such as Jappe and the Principia Dialectica group, ${ }^{123}$ Debord's move away from a focus on labour is one of his chief virtues. Whilst making reference to Lukács' 1967 preface to History and Class Consciousness Jappe contends that the latter book's corrected presentation of labour as a constitutive force "turn[ed] a characteristic of capitalism into an eternal ontological necessity". ${ }^{124}$ For Jappe, such a fixation on the primacy of labour and class denigrates their historical mutability and thus their potential supersession. ${ }^{125}$ Yet neither Lukács nor the Marx of the Manuscripts equate all constitutive activity to contemporary capitalist labour, and there remains a marked difference between recognising the characteristics of present circumstances and casting them as absolutes. Consequently, and as opposed to those who would hold that the relevance of Debord's theory lies in its resonance with contemporary issues of real abstraction, I would contend that the theory is itself simply too abstract.

Having made these claims I will now return to my earlier proposal that Debord's concerns with temporality may offer more than a means of correcting the interpretation of Debord's spectacle and of highlighting its shortcomings. In the sections below l'll suggest that it can also be seen to indicate some of the more interesting aspects of his Hegelian Marxism, particularly vis a vis the latter's connection to his connection of historical and strategic thought.

120 Debord 1995, p.29; Debord 2006, p.779

121 S.I. 2006 p.147; S.I. 1997, pp.323-4

122 For Postone, "the working class is integral to capitalism rather than the embodiment of its negation" (Postone 1996 17, Postone's italics).

${ }^{123}$ For the Principia Dialectica group Debord did not move far enough from a concern with production. See the group's website at: www.principiadialectica.co.uk.

124 Jappe 1999, p.151

125 Jappe 1999, p.151 


\section{Time and contingency}

As noted above, the publication of Debord's A Game of War in 2007 has furthered interest in his status as a 'strategist'. An awareness of this dimension of his thought and work has also been encouraged by the flurry of intellectual biographies that appeared over the last decade. Yet in the absence of the themes of time and subjectivity that l've drawn attention to above, this interest can appear to be a mere idiosyncrasy, and thus a means by which an author might add a degree of shade to his portrait. Merrifield, for example, enjoys picturing a melancholy philosopher-poet given to "ruminate" on "quiet, lonely summer days" over classics of military theory; ${ }^{126}$ Hussey presents a self-consciously Machiavellian figure, and Bracken ${ }^{127}$ similarly describes a "player of human chess". ${ }^{128}$ Although other writers have attempted more detail, ${ }^{129}$ the theoretical dimensions of Debord's interest in strategy and its connection to the more existential aspects of his account remain largely ignored.

However, if as a result of its identity with time the subject is located in perpetual opposition to its present - even to the reality that it has itself created, and by extension to its own extant self - then that subject is inherently transitory, and characterised by finitude. Particular forms of consciousness would then be bound to particular moments and contexts, precluding any absolute, trans-historical viewpoint. Actions would thus have to be based upon limited knowledge of the factors in play, and this in turn means that the dialectical relation between subject and world described above must inevitably involve chance (Debord: "all progress, all creation, is the organization of new conditions of chance"). ${ }^{130}$ In other words, the construction of history becomes a strategic enterprise: or as Debord put it whilst quoting Clausewitz, "one must become accustomed to acting in accordance with general probabilities; it is an illusion to wait for a time when one will be completely aware of everything". ${ }^{131}$

This homology between existential and strategic concerns ${ }^{132}$ pertains to

\footnotetext{
126 Merrifield 2005, p.11

127 Bracken's book does contain some genuine insight: "for Debord [the] apprehension of time was coloured [by a] Hegelian preoccupation with the self-conscious creation of history with acts of negation". (Bracken 1997, p.105).

128 Bracken 1997, p.viii

129 Jappe (1999, p.114) proposes that Debord's interest in strategy "could be interpreted as a desire to remain moored to a world still essentially intelligible ... and to a high degree predictable". Strategic thought is however an attempt to think with chance, not against it, and it is of interest to Debord because time renders the world inherently unpredictable. Kaufmann (2006, p.209) reads Debord under the rubric of poetic melancholia, and thus turns a concern with actualising the negativity of time into the tragic acceptance of a time that simply happens to us: Debord was concerned with "war and loss", he claims, because "they are two faces of the same hunger for the irrevocable, for experiences that are lost forever". More interestingly, Wark $(2008$, p.28) has suggested that Debord's Game of War is "really a diagram of the strategic possibilities of spectacular time" $\square$, but he leaves this claim undeveloped.

130 Debord 2006, p.296

131 Debord 2003, p.180; Debord 2006, p.1388

132 The sense in which Debord's subject is always located within a given context, is characterised by limited
} 
the S.I.'s goal of transforming life into a game, ${ }^{133}$ and as I'll show in a moment it also becomes particularly significant in relation to Debord's views on Marx's 'inversion' of Hegel. First however, and in order to introduce the 'openness' of Debord's Hegelian view of history, I'll offer some comments on the manner in which these issues entail that 'truth' - as opposed to the spectacle's 'falsity' corresponds to historical action and to the contextuality of praxis.

As we've seen, the subject's identity with time necessitates autonomy and self-determination, and thereby precludes political representation ${ }^{134}$ (as the S.I. put it: "We will only organize the detonation: the free explosion must escape us and any other control forever"). ${ }^{135}$ This is not however to suggest that Debord and the S.I. were in favour of "sub-anarchist spontaneism": according to the S.I., anyone who associated them with the latter would show that they "simply don't know how to read." 136 Their interpretation of councilism does however differ sharply from Lenin's own disavowal of 'spontaneity': for where Lenin held that the latter would constitute "nothing more nor less than consciousness in an embryonic form", ${ }^{137}$ Debord maintained that the knowledge required to deal with an insurrectionary situation could never be 'imputed' by external, intellectual managers, ${ }^{138}$ but must develop immanently through praxis. ${ }^{139}$ This could not take place through the imposition of an identity or a 'correct' ideological perspective, but only through the expression of a shared circumstance or problematic. Hence Debord's claim that "we did not 'put our ideas into everybody's heads' ${ }^{140}$ by the exercise of some outside influence or other," but rather "gave voice to ideas that were necessarily already present in these proletarian heads". ${ }^{141}$ Consequently, whilst Debord certainly employs a Hegelian notion of recognition - both in terms of the acceptance of theory, but also notably within the councils themselves ${ }^{142}-$ this

knowledge and shapes itself through actualising projects clearly echoes aspects of Sartre's account in Being and Nothingness. One can however also detect further homologies: e.g. "we must decide upon the opportuneness of an act and attempt to measure its effectiveness without knowing all the factors that are present" (De Beauvoir 1976, p.123); "the only situation a commander can know is his own" (Clausewitz 1993, p.95), as "war is the realm of uncertainty" (Clausewitz 1993, p.117).

133 "In the whole range of human activities, war most closely resembles a game of cards" (Clausewitz 1993, p.97); Cf. Debord's call for a "ludic model of time" (Debord 1995, p.116, translation altered; Debord 2006, p.836), and his observation that "one fights also by playing" (Debord 2002, p.81, translation altered; Debord 2006, p.1641)

134 'We shall never begin to understand Debord's hostility to the concept 'representation,' for instance, unless we realize that for him the word always carried a Leninist aftertaste. The spectacle is repugnant because it threatens to generalize, as it were, the Party's claim to be the representative of the working class." (Clark and Nicholson Smith 2004, p.479)

135 SI 2006, p.148; S.I. 1997, p.324

136 S.I. 2006, p.356; S.I.1997, p.637

137 Lenin 1988, p.97

138 "The task of directing the proletariat from without, by means of a disciplined clandestine party under the control of intellectuals who had become 'professional revolutionaries', gave rise to a genuine profession ... of total social management" (Debord 1995, p.68, emphasis in the original; Debord 2006, p.805)

139 See theses 123 and 203 of The Society of the Spectacle (Debord 1995 p.89 and 143; Debord 2006, p.819 and 829).

140 An unattributed quotation from the S.I.'s article 'New Forms of Action against Politics and Art', first published in Internationale Situationniste 11 (S.I. 2006, pp.275; S.I. 1997, pp.529).

${ }^{141}$ S.I. 2003, p.9 emphasis in the original, translation altered; Debord 2006, p.1089

142 "The power of workers' councils ... aspires to be recognised - and to recognise itself - in a world of its 
does not involve giving voice to a stable ontological truth, but rather to the acknowledgement of a temporary exigency; and as validity stems from an ability to diagnose and affect an existing historical tendency, the recognition and adoption of theory on the part of those who are to actualise it serves as the measure of its truth. ${ }^{143}$ Hence Debord's claim that Marx's Capital is "obviously true and false: essentially, it is true, because the proletariat recognized it, although quite badly (and thus also let its errors pass)"; 144 hence also his own and the S.I.'s view that the events of May 1968 demonstrated the truth of their own arguments. ${ }^{145}$

The subject's identity with time thus casts historical action as a strategic enterprise. Yet in doing so, it entails that theoretical truth must itself be contingent, or at least historically contextual. ${ }^{146}$ Consequently, the existential aspects of Debord's account and its opposition to representation entail that theory can only provide the articulation and clarification of a given moment, and this, as I will now suggest, connects to the anti-dogmatism that characterises his Hegelianism.

\section{History and Hegelian Marxism}

Debord's view of the relation between Marx and Hegel can be introduced by looking at the manner in which Debord held Marx to have "demolish[ed] Hegel's detached stance with respect to what occurs". ${ }^{147}$ Having rejected any species-being, essence or telos that might require full historical expression, Debord claimed that after Marx "theory thenceforward had nothing to know beyond what it itself did". ${ }^{148}$ This can be clarified by noting Debord's admiration for Cieszkowski's Prolegomena for a Historiosophy; a work that he did not discover until "after 1972"149 (and which he published through Champ Libre the following year), but which echoes many of the themes presented in 1967's The Society of the Spectacle. Cieszkowski's significance, in Debord's view, was to have laid - "five years before the young Marx, and one hundred and twenty years before the Situationists" - the "primary basis" upon which "the modern project of the social revolution is constituted." 150 Debord writes as follows:

Cieszkowski annihilates the central aporia of the [Hegelian] system, simply by

own design" (Debord 1995, p.127, emphasis in the original; Debord 2006, p.842).

${ }^{143}$ A view that perhaps owes much to Marx's claim in his 'Theses on Feuerbach' that "Man must prove the truth ... in practice" (Marx 2005, p.171).

144 Debord 2004, p.457

145 See the S.I.'s 1969 essay 'The Beginning of an Era' (S.I. 2006 pp.288-325; S.I. 1997, pp.571-602

${ }^{146}$ For Debord, a theory "can indeed be relatively 'false' - and thus 'true for historical thought - in that it is only 'the maximum of possible consciousness' at this moment in society, which one will explain much better after one has left it behind or when one will be more advanced in the endeavour to leave it". Debord 2004, p.456

147 Debord 1995, p.51, emphasis in the original; Debord 2006, p.795

148 Debord 1995, p.51; Debord 2006, p.795

149 Debord 2008, p.84

150 Debord 1983 
recalling that time had not ended. Hegel had concluded history, in the form of thought, because he finally accepted the idea of glorifying the present result. In a single movement, Cieszkowski reversed the system, by putting the present in contact with the "moment" of the future, because he recognized in the thought of history - the supersession of philosophy - the power to transform the world. ${ }^{151}$

Cieszkowski's actual objection is in fact slightly different: he contends that Hegel, in limiting his focus to the past, failed to think history as a totality, ${ }^{152}$ although he does maintain that philosophy is to be realised as praxis. ${ }^{153}$ The salient point here however is the degree to which the statement above illuminates Debord's own view of the relation between Marx and Hegel. It certainly chimes with the account presented in The Society of the Spectacle: there Debord claimed that the crux of Marx's famous 'inversion' was not the "trivial substitution"154 of unfolding categories for developing social relations, but rather a more 'horizontal' shift in perspective; for where Hegel cast the present as the conclusion of the past, Marx is viewed as having rendered every present moment the genesis of an open future. After Marx, Debord writes, "history, once it becomes real, no longer has an end."155 There is thus no grand cosmological truth or human telos, but only that which is created through collective action: for doing away with any notion of an intrinsic human essence in favour of an identity with time entails an inherently 'open' historical dialectic.

However, I would suggest that this is not a dialectic without resolution per se. Rather than a goal located at the apex of history (i.e. as an epiphany or a particular state of affairs within history), Debord seems to cast subjectobject unity as the circular self-perpetuating grounds of an open-ended process: for history "has no goal [n'a pas d'objet] aside from whatever effects it works upon itself". ${ }^{156}$ The same is true on the individual level: life was to become "a journey containing its whole meaning within itself". 157

This can be clarified by distinguishing it from Lefebvre's historical goal of a 'total' or "'de-alienated' man". ${ }^{158}$ A "living subject-object"159 said to arise immanently from the privations and demands of everyday life, the 'total man' constituted a reaction to the purportedly a-political relativism of existential freedom, ${ }^{160}$ but did so by functioning more as a perpetually receding

\footnotetext{
151 Debord 1983

152 "The totality of history must consist of the past and of the future, of the road already travelled as well as the road yet to be travelled". Cieszkowski 2009, p.51

153 "The future of philosophy in general is to be practical philosophy or, to put it better, the philosophy of praxis." Cieszkowski 2009, p.77 emphasis in the original.

154 Debord 1995, p.51; Debord 2006, p.794

155 Debord 1995, p.51; Debord 2006, p.795

156 Debord 1995, p.48; Debord 2006, p.792

157 Debord 1995, p.126; Debord 2006, p.842

158 Lefebvre 1968, p.162

159 Ibid.

160 "Existentialism is the philosophy ... of abstract freedom ... the reactionary side of existentialism's present influence is here concealed" (Lukács 1973). For Lefebvre, by contrast, "only the notion or idea of the absolute [i.e. the total man] gives a sense (in other words both a meaning and a direction) to historically acquired knowledge" (Lefebvre 2008a, p.67).
} 
directional beacon than as an attainable status. ${ }^{161}$ Lefebvre's own deliberately anti-dogmatic dialectic can be seen to maintain its 'openness' through the constant deferral of that final synthesis. Debord on the other hand - who is perhaps closer to Hegel in this regard than he may have realised - founds his own 'open' dialectic upon the establishment of the subject-object unity that Lefebvre defers.

Casting subject-object unity as the condition for the full flourishing of historical agency Debord would seem to put Debord close to Lukács once again. Yet for Lukács, "no path leads from the individual to the totality," 162 as "the form taken by the class consciousness of the proletariat is the Party". ${ }^{163}$ Insofar as the party alone constitutes the historical self-consciousness of the proletariat it remains necessary insofar as that historical agency persists: the conditions for a permanently open history are thus the conditions for the permanence of the party form, and thus in Debord's view for the perpetuation of an "external [extérieure]" 164 power tasked with "directing the proletariat from without [la direction extérieure du prolétariat]". ${ }^{165}$ This is of course untenable for Debord. Abstract though his own and the S.I.'s redefinition of the proletariat may be, its implications can be seen to offer a clarification or rectification of Lukács views on historical self-consciousness: for if subjectobject unity is in essence an agency that is at the same time a selfdetermining process, Debord's emphasis on direct, collective selfdetermination in workers' councils is perhaps arguably more coherent in this regard than Lukács' insistence on party mediation (Debord: "once embodied in the power of workers' councils ... the proletarian movement becomes its own product; this product is the producer himself, and in his own eyes the producer has himself as his goal"). ${ }^{166}$

I would suggest that subject-object unity becomes an entirely selfdetermining ground of action in Debord's account: a form of dialectical resolution, but one that nonetheless remains perpetually 'open' insofar as it continually reformulates its own grounds. If this is so, Debord could perhaps be viewed as presenting something similar to Raya Dunayevskaya's own Hegelian Marxism, which was not modelled upon any particular stage along the paths towards Hegel's 'Absolute' (e.g. the unhappy consciousness or the lord and bondsman, both of which inflect Debord's concerns with time and negativity via their import within French Hegelianism), but rather upon the Absolute itself: for according to Hegel, the latter perpetually recreates itself and generates differentiation from itself by virtue of its own, self-determining

161 The total man is presented as "a figure on a distant horizon beyond our present vision" (Lefebvre 2008a, p.66), and described as a "mathematical limit" to which "we are forever drawing nearer but have never reached" (Lefebvre 1968, p.109). His theory of 'moments' (which was close in many respects to the S.I.'s situations) describes fleeting contact with this goal, whilst maintaining its status as "an ever-sought and ever-inaccessible absolute" (Lefebvre 2008b, p.355).

162 Lukács 1971, p.28

163 Lukács 1971, p.41, emphasis in the original

164 Debord 1995, p.81; Debord 2006, p.814

165 Debord 1995, p.68; Debord 2006, 805

166 Debord 1995, p.87; Debord 2006, p.818 
and self-perpetuating necessity. The subject-object unity presented within Debord's work can thus be seen to render the "life-pulse" 167 of the Concept (Begriff) as a continual interplay between subject and object, driven by the "universal blood"168 of the negativity and difference of time. One could even go so far as to suggest that what Debord offers here is something close to a notion of general will, ${ }^{169}$ albeit one without a "sovereign" (regardless of Rousseau's claim that the latter "cannot be represented"); ${ }^{170}$ it's thus perhaps worth noting that for T.J. Clark "the Debord-Rousseau comparison is inescapable". ${ }^{171}$

We might now begin to return to the linkage of historical and strategic thought that I signalled at the outset. I've emphasised the sense in which strategy can be seen to relate to the subjective, historical projects that Debord associated with the authentic temporality denied by spectatorship. I've also suggested that this connection between strategy and history stems from Debord's incorporation of an almost Sartrean notion of situational, limited and future-oriented consciousness into a form of Hegelian Marxism. This can now be clarified by noting that it results from his presentation of Marx's 'realisation' of Hegelian philosophy as a form of (Hegelian) development: i.e. as having rendered explicit that which was implicit within Hegel's philosophy. Marx is viewed as showing the latter to imply not Hegel's own retrospective historical self-consciousness of a history that had already happened, but rather the self-consciousness of a history that was to be made via proactive praxis. History becomes agency, and a quasi-existential concern with situational, contextual consciousness and self-determination is thus inserted into that Hegelian schema, thereby entailing a concern with strategy. In consequence, historical and strategic thought become one, producing a mode of thought that "allow[s] one" (as Debord put it when describing his own "strategic capabilities") to "see where one is truly going", ${ }^{172}$ but which relies upon the identity and critical capabilities that stem from knowing where one has been. With that in mind, we might now return to Debord's contention that spectacular society 'can no longer be led strategically'.

\section{Strategy and tactics in Debord's Comments on the Society of the Spectacle}

So why might the spectacular state be unable to function strategically, and how might that pertain to the nature of the spectacle? In order to answer we should begin by looking at Debord's account of the 'integrated' spectacle,

\footnotetext{
167 Hegel 1998, p.37

168 Hegel 1977, p.100

169 Cf. Hallward's considerations of a form of general will that would "make the way by walking it" (Hallward 2009, p.17).

170 "Sovereignty cannot be represented, for the same reason that it cannot be alienated; its essence is the general will, and will cannot be represented" (Rousseau 2004, p.112).

171 See Clark's foreword in Jappe 1999, p.viii

172 Debord 2008, p.371
} 
which he presented in the Comments as a unification of the 'diffuse' (commodity capitalism) and 'concentrated' (fascism, state bureaucracy) forms described in The Society of the Spectacle, but which also, as noted above, was said to have "integrated itself into reality." 173

Debord describes the spectacle's advances since 1967 in terms of an encroaching military force, ${ }^{174}$ and claims that it has given rise to an increased denigration of historical thought. As history is the "measure of genuine novelty", ${ }^{175}$ he claims that its erasure aids falsification and furthers the propagation of "unverifiable stories, uncheckable statistics, unlikely explanations and untenable reasoning." ${ }^{176}$ As a result, there is "no room for any reply" 177 to spectacular discourse, resulting in the subordination of dialogue to the spectacle's "enormous positivity". ${ }^{178}$ This gives rise to a "dissolution of logic", ${ }^{179}$ furthered by the media's imposition of a kind of generalised immediacy. ${ }^{180}$ The continuity and development of thought and subjectivity through opposition is thus stifled, denigrating "even ... the dialectical logic of conflicts"; 181 and in the consequent absence of any coherent opposition, the spectacle focuses upon itself and its own imagined enemies. "Surveillance and intervention" 182 thus become increasingly important, and "operate on the very terrain of this threat in order to combat it in advance." 183

This last point is alluded to again in the book's somewhat cryptic penultimate section. Debord quotes Clausewitz's classical definition of strategy and tactics ("tactics teaches the use of armed forces in the engagement; strategy, the use of engagements for the object of the war"), ${ }^{184}$ and following a long discussion of the manner in which the introduction of new weaponry in the Napoleonic era gave rise to new tactics Debord indicates that the spectacle's development and 'integration' will give rise to similar revelations on the part of its rulers; ${ }^{185}$ a point that pertains to his view that conflicts are possessed of a 'dialectical logic' that engender development on both sides. Yet whilst doing so, he also draws attention to Napoleon's

\footnotetext{
173 Debord 2002, p.9; Debord 2006, p.1598

174 Debord 2002, p.4; Debord 2006, p.1595

175 Debord 2002, p.15; Debord 2006, p.1602

176 Debord 2002, p.16; Debord 2006, p.1602

177 Debord 2002, p.29; Debord 2006, p.1610

178 Debord 1995, p.15; Debord 2006, p.769

179 Debord 2002, p.27; Debord 2006, p.1609

180 "When social significance is attributed only to what is immediate, and to what will be immediate immediately afterwards, always replacing another, identical, immediacy, it can be seen that the uses of the media guarantee a kind of eternity of noisy insignificance" (Debord 2002, p.15; Debord 2006, p.1602)

181 Debord 2002, p.31; Debord 2006, p.1611

182 Debord 2002, p.84; Debord 2006, p.1643

183 Debord 2002, p.84, emphasis in the original; Debord 2006, p.1643

184 Clausewitz 1993, p.146; Debord 2002, p.85; Debord 2006, p.1644

185 "Similarly, the establishment of spectacular domination is such a profound social transformation that it has radically altered the art of government ... those who serve the interests of domination ... [will] clearly see what obstacles they have overcome, and of what they are capable." (Debord 2002, pp.87-8; Debord 2006, pp.1645-6
} 
"strategy ... of using victories in advance". ${ }^{186}$ The spectacle's manipulation of its own opposition would thus seem to be linked to Napoleon's skill at dictating the actions of his enemies. It might also be noted that Debord's comments on Napoleons' ability to use victories "as if acquired on credit"187 seems to stem from Clausewitz's analysis; the latter claimed that "Bonaparte could ruthlessly cut through all his enemies strategic plans in search of battle, because he seldom doubted the battle's outcome". ${ }^{188}$ As strategy is influenced by tactical events, tactical superiority (in terms of the manoeuvre to battle) and successes (in terms of its victory) can sabotage the enemy's strategy; and as Clausewitz stresses, Napoleon's success stemmed from allowing tactical events to shape his own unfolding strategy and to confound that of his opponents.

Debord would seem to be implying that the symptoms of the spectacle's 'integration' into society - and thus of its eradication of history - constitute a similar ability to 'ruthlessly cut through' an enemy's strategy (which as we've seen is connected to historical consciousness); hence his connection of Napoleonic "changes in the art of war"189 to spectacular "changes in the art of government." 190 Yet he also maintains that history's eradication has resulted in a lack of coherent organisation and continuity. It would thus seem that although the spectacle is able to organise its own opposition 'in advance', its 'strategy' is dictated purely by the momentum of its own tactical victories; a momentum that military historians have described as both the strength and the weakness of Napoleon's approach: according to Handel, for example, its danger is that "instead of becoming the driving force in war, strategy becomes a mere by-product or afterthought". ${ }^{191}$

For Debord, "an all-powerful economy" has become "mad" (this, he claims, is "precisely what defines these spectacular times"), ${ }^{192}$ and now ploughs on towards self-destructive situations; whilst discussing ecological issues, Debord remarks that it "has now come to declare open war against humans; not only against their possibilities for life, but against their chances of survival". ${ }^{193}$ It's perhaps also significant that Clausewitz's own comments about Napoleon's approach to strategy are made during a discussion of the art of defending against enemy invasion: referencing Napoleon's Russian debacle of 1812, ${ }^{194}$ Clausewitz stresses, in suitably dialectical fashion, that

\footnotetext{
186 Debord 2002, p.86, emphasis in the original; Debord 2006, p.1644

187 Ibid.

188 Clausewitz 1993, p.462

189 Debord 2002, p.85; Debord 2006, p.1644

190 Debord 2002, p.87; Debord 2006, p.1645

$191 \quad$ Handel 2006, p.354

192 Debord 2002, p.39, emphasis in the original; Debord 2006, p.1616

193 Ibid., translation altered

194 In 1812 the Grande Armée advanced into Russia. Alexander's forces retreated, and employed a scorched earth policy as they did so. When the exhausted and starving French finally reached Moscow Napoleon was able to claim the city. However, as three quarters of it had been burned, and as the Tsar would not come to terms, Napoleon had no choice but to abandon Moscow and retreat back to Poland. During the course of this retreat he was forced to fight again at Beresina. When the returning army finally entered Poland its original force of 420,000 had been cut down to 10,000 (Handel 2006, p.194).
} 
the further an attack progresses the weaker it becomes; and it would seem that for Debord the spectacle's absence of strategic guidance entails that it too is to advance beyond what Clausewitz refers to as its 'culminating point'. 195

In his later years Debord maintains his 1967 contention that the increasing abundance of spectacular commodities is inversely proportional to their ability to satisfy; a position that he maintains into the 1990 's. ${ }^{196} \mathrm{He}$ also seems to hold that the spectacle's progress from concentration through diffusion to integration has caused the spectacle to wear increasingly thin:" the same question," he wrote in 1992, "is about to be posed again everywhere: how can the poor be made to work once their illusions have been shattered, and once force has been defeated?"197 I would thus contend, and as opposed to the writers mentioned above who would present the Comments as overtly 'pessimistic', that Debord is still maintaining the merits and possibility of mass political action (in a letter referring to his work on the book he himself joked that "the work of revolutionary critique is assuredly not to lead people to believe that the revolution has become impossible!"). ${ }^{198}$

The problem, however, is the manner in which this opposition was to arise. This notion of weakening illusions was coupled to an alleged increase in the quasi-existential poverty described above, and in consequence Debord's later writings bring the problematic aspects of his earlier account to the fore. "Each person", Debord complains in 1985, "no longer has an individual history in and through which he discovers and forms his own tastes". ${ }^{199}$ Such 'individual history' was to emerge from the classless ennui of spectacular consumption, rather than from the oppositional relations and antagonistic experiences of capital; ${ }^{200}$ and in dismissing "the immense efforts that have been made by the 'practical men' of our era to manage to not understand what is most important", Debord concludes that "it is only necessary to know how to love."201

\section{Conclusion}

195 "Beyond that point the scale turns and the reaction follows with a force that is usually much stronger than that of the original attack. This is what we mean by the culminating point of the attack" (Clausewitz 1993, p.639).

196 In a letter of 1990 Debord predicts that that increasingly reasonable demands (e.g. water "that does not send one to the hospital" (Debord 2008, p.233) will become increasingly revolutionary, and that the spectacle's promises will become ever more insubstantial.

197 This quotation is from Debord's 1992 preface to the third French edition of The Society of the Spectacle (Debord 1995, p.10; Debord 2006, p.1794).

198 Debord 1986

199 Debord 1985; Debord 2006, p.1583

200 This results in some alarmingly parochial views. We are told, Debord complains, that "the planet produces enough cereal that no one should suffer hunger, but what troubles this idyll is that the 'rich countries' abusively consume half the world's cereals in feeding their cattle. But when one has known the disastrous taste of butchered meat which was thus fattened on cereal, can one speak of 'rich countries'? It's not to make us live like Sybarites that part of the planet is dying of famine; it's to make us live in the mud" (Debord 1985; Debord 2006, p.1585).

201 Debord 2008, p.284 
That rather banal assertion can be seen to stand in contradiction to the implications of Debord's Hegelian Marxism: firstly, insofar as the notion that the spectacle will continue to advance beyond its 'culminating point' echoes the passivity that Debord attributed to economic determinism, thus contradicting his focus on pro-active, constitutive action within time; and secondly, to the degree that the abstract subjectivism of the concept of spectacle, which this assertion reflects, can be seen to contradict the need to study a historical context in sufficient depth to be able to affect and move beyond it. This can be elaborated by noting that the anti-dogmatism and drive towards action and reformulation that characterises Debord's Hegelian Marxism casts theoretical works as being akin to tactical interventions: they are only as valid as their ability to define or affect a given context, and are thus specific to that context As Debord himself put it:

Theories are only made to die in the war of time. Like military units, they must be sent into battle at the right moment; and whatever their merits or insufficiencies, they can only be used if they are on hand when they are needed. But they have to be replaced because they are constantly being rendered obsolete - by their decisive victories even more than by their partial defeats. ${ }^{202}$

However, Debord's own views on his theory would seem to depart from this. In 1979 he declared that he had "no doubt that the confirmation all my theses encounter" would "last right until the end of the century and even beyond"; 203 according to Prigent's anecdote, Debord thought this period of validity would extend as far as $2030 .^{204}$

I've attempted to show that both this assumption and the drive towards reformulation that it would seem to contradict stem from Debord's concerns with time. On the one hand, that concern furthers his focus on praxis and antidogmatism. Yet on the other, it also informs his overly subjective perspective; a perspective that engendered disconnection from the changing realities of historical struggle through its abstraction and romanticisation of the latter. I would contend, therefore, that one can discern an internal contradiction within Debord's work: a contradiction between the theory of spectacle and the ideas that found it, insofar as the latter would seem to imply the contextuality and thus the consequent supersession of the former. The implication is that this more foundational material points beyond the theory that rests upon it.

I opened this essay by discussing the degree to which the S.I. had been 'recuperated' by art, culture and academia, and suggested that the ease with which this assimilation had been achieved might indicate that their output was perhaps not quite as 'noxious' as some might like to believe. Through the discussions above l've attempted to show how this might be seen to connect

\footnotetext{
202 Debord 2003, pp.150-1; Debord 2006, p.1354

203 Debord 1979a; Debord 2006 p.1465

204 "Around 1982, [Debord] told me that his 1967 La Société du Spectacle would be valid for the next fifty years. I told him: 'Are you sure?' His answer was categorical, his book would last for that period of time" (Prigent 2009).
} 
not only to the theory of spectacle's somewhat opaque visual terminology, but also to its replacement of social antagonism with a dichotomy between 'life' and its denial. I've addressed this by way of Debord's linkage of historical and strategic thought, which I pursued through Debord's concerns with time and history, and I hope that in doing so I've succeeded in opening up some of the more interesting and relevant aspects of his Hegelian Marxism. This, I would argue, is a version of Hegelian Marxism that avoids any notion of final telos or original essence, and which is opposed to party representation: it presents subject-object unity as the grounds of collective self-determination rather than as an ineffable goal, and is inherently opposed to any stratification into dogma. And, given that it would seem to actively invite the theory of spectacle's supersession, I would propose that Debord's views on time, history and dialectics may be of potentially greater contemporary interest than that of their ability to clarify his work.

\section{REFERENCES:}

Agamben, Giorgio, 1990 'Marginal Notes', available at: www.zinelibrary.info/files/Marginal\%20Notes\%20-\%20PRINT_0.pdf Aufheben, 1997, 'Whatever Happened to the Situationists?', Aufheben 6. ------2009, 'Capitalism and Spectacle - The Retort Collective's Afflicted Powers', Aufheben 17.

De Beauvoir, Simone, 1976, The Ethics of Ambiguity, New York: Citadel Press.

Becker-Ho, Alice, and Debord, Guy, 2007, A Game of War, London: Atlas Press.

Beller, Jonathan, 2006, The Cinematic Mode of Production - Attention Economy and the Society of the Spectacle, Hannover, NH: Dartmouth College Press.

Berardi, Franco, 2004, 'The Premonition of Guy Debord' available at www.generation-online.org/t/tbifodebord.htm

Best, Steven, and Kellner, Douglas, 2000, 'Debord and the Postmodern Turn: New Stages of the Spectacle', available at: www.uta.edu/huma/illuminations/kell17.htm

Bracken, Len, 1997, Guy Debord - Revolutionary, Feral House, Venice, California

Brown, Bill, 1991, 'Guy Debord's Comments on the Society of the Spectacle', in Notbored! 19, available at www.notbored.org/comments.html Cieszkowski, August, 2009 (1838), 'Prolegomena to Historiosophy', in Selected Writings of August Cieszkowski, Liebich, André (ed.),Cambridge University Press, London

Clark, T.J., and Nicholson-Smith, Donald, 2004 (1997), 'Why Art Can't Kill the Situationist International', in McDonnough (ed.), Guy Debord and the Situationist International - Texts and Documents, October, London Class War Games, 2010, 'Class War Games Presents Guy Debord's The 
Game of War', available at: www.classwargames.net

von Clausewitz, Carl, 1993 (1832), On War, New York: Princeton University Press

Crary, Jonathan, 2001, Suspensions of Perception - Attention, Spectacle and

Modern Culture, Cambridge, Massachusetts: MIT Press

2004, 'Spectacle, Attention, Counter-Memory', in McDonnough (ed.),

Guy Debord and the Situationist International - Texts and Documents, London: October

Dark Star, 2001, Beneath the Paving Stones - Situationists and the Beach, May 1968, Edinburgh: AK press

Dauvé, Gilles, 1979, (writing under the pseudonym Jean Barrot), 'Critique of the Situationist International', available at:

www.geocities.com/ johngray/barsit.htm

Debord, Guy, 1969, Letter to the Italian Section of the S.I., 27th May, available at: www.notbored.org/debord-27May1969.html 1973, Letter to Jaap Kloosterman, June 18th, available at www.notbored.org/debord-31January1973.html

1974, Letter to Eduardo Rothe', $21^{\text {st }}$ February, available at www.notbored.org/debord-21February1974.html

1979a, Letter to Michel Prigent, 7th December, available at www.notbored.org/debord-7December1979.html

$1979 \mathrm{~b}$, 'Preface to the Fourth Italian Edition of The Society of the Spectacle'

www.notbored.org/debord-preface.html

1980, Letter to Mikis Anastassiadis, 5 August 1980, available at

http://www.notbored.org/debord-5August1980.html

1983, Letter to Gerard Lebovici, ${ }^{\text {rd }}$ May, available at

http://www.notbored.org/debord-3May1983.html

1985, 'Abat Faim', available at www.notbored.org/abat-faim.html

1986, Letter to Jean-Francois Martos, $19^{\text {th }}$ December, available at

http://www.notbored.org/debord-19December1986.html

------1986, Letter to Jean-Francois Martos, $19^{\text {th }}$ December, available at

http://www.notbored.org/debord-19December1986.html

-----1993, Cette Mauvaise Reputation, Gallimard, Paris

1995, (1967) The Society of the Spectacle, Zone Books, New York, 2002, (1988) Comments on the Society of the Spectacle, Verso, London 2003, Complete Cinematic Works - Scripts, Stills and Documents,

Knabb, Ken (ed.), Edinburgh: AK Press

2004, Correspondance Volume 4: Janvier 1969 - Décembre 1972,

Poitiers: Libraire Arthème Fayard

2006, Oeuvres, Malesherbes: Gallimard

2008, Correspondance Volume 7: Janvier 1988 - Novembre 1994,

Vottem: Libraire Arthème Fayard

------2009, Correspondence - The Foundation of the Situationist International, Los Angeles: Semiotext(e) 
Feuerbach, Ludwig, 1989 (1841), The Essence of Christianity, New York:

Prometheus Books

Gallix, Andrew, 2009, 'The Resurrection of Guy Debord', in The Guardian,

Wednesday $18^{\text {th }}$ March, available at:

www.guardian.co.uk/books/booksblog/2009/mar/18/guy- debord-

situationist-international

Hallward, Peter, 2009, 'The Will of the People: Notes Towards a Dialectical

Voluntarism', in Radical Philosophy 155

Handel, Michael, 2006 (1992), Masters of War-Classical Strategic Thought,

Routledge, Abingdon

Hardt, Michael, and Negri, Antonio, 2001, Empire, Harvard University Press,

London

Hegel, GWF, 1977, (1807) The Phenomenology of Spirit, Oxford University

Press, Oxford, 1977

1998 (1831), The Science of Logic, Humanity Books, New York

2005 (1821) The Philosophy of Right, Dover, New York,

Heidegger, Martin, 2008 (1927), Being and Time, Blackwell, Oxford

Hussey, Andrew, 2002, The Game of War - The Life and Death of Guy

Debord, Pimlico, London

Jay, Martin, 1994, Downcast Eyes - The Denigration of Vision in Twentieth

Century French Thought, University of California Press, Berkeley

Jappe, Anselm, 1999, Guy Debord, University of California Press, London

Kaufmann, Vincent, 2006, Guy Debord - Revolution in the Service of Poetry,

University of Minnesota Press, Minneapolis

Lefebvre, Henri, 1968 (1940), Dialectical Materialism, Jonathan Cape,

London

2008a (1947), Critique of Everyday Life: Volume 1, Verso, London

2008b (1961) Critique of Everyday Life: Volume 2, Verso, London

Lenin, Vladimir Ilich, 1988 (1902), What is to be Done?, Penguin, London

Lukács, Georg, 1971 (1923), History and Class Consciousness, Merlin,

London

------1973 (1949) ,'Existentialism', available at:

www.marxists.org/archive/lukacs/works/1949/existentialism.htm

Marx, Karl, 1988 (1932), Economic and Philosophical Manuscripts of 1844,

Prometheus Books, New York

1990 (1867), Capital (Volume 1), Penguin, London,

2005, Karl Marx - Selected Writings, McLellan, David (ed.), Oxford:

Oxford University Press

Merrifield, Andy, 2005, Guy Debord, London: Reaktion Books

Mitchell, W.J.T., 1995, Picture Theory, London: University of Chicago Press

Plant, Sadie, 2000, The Most Radical Gesture - The Situationist International

in a Postmodern age, New York: Routledge

Prigent, Michel, 2009, 'The Difference between Moishe Postone's and Guy

Debord's Critique of Capitalism, or: The Limits of Guy Debord', available at

http://www. principiadialectica.co.uk/blog/?p=575 
Rousseau, Jean-Jacques, 2004 (1762), The Social Contract, London:

Penguin

Sartre, Jean-Paul, 1973, (1946) Existentialism and Humanism, Methuen, London

Situationist International, 1997, Internationale Situationniste: 1958-1969, Mayenne: Libraire Arthème Fayard

------2003, Situationist International Anthology, Knabb, Ken (ed.), Berkeley:

Bureau of Public Secrets,

2003 (1972), The Real Split in the International, London: Pluto Press

Sun Tzu, The Art of War, Shambhala, Boston, Massachussets, 1988

Vaneigem, Raoul, 2003 (1967), The Revolution of Everyday Life, London:

Rebel Press

Voyer, Jean-Pierre, 1998, 'There is no Society of the Spectacle', available at http://pagesperso-orange.fr/leuven/arideau.htm\#_ftn1

Wark, McKenzie, 2008, 50 years of Recuperation of the Situationist International, New York: Princeton Architectural Press

Weizman, Eyal, 2006, 'The Art of War', in Frieze, 99, 2006, available at: www.frieze.com/issue/article/the_art_of_war/ Weizmann 